\title{
Ion Transport in Plant Cell Shrinkage During Death
}

\author{
François Bouteau ${ }^{1 *}$, David Reboutier ${ }^{2}$, Daniel Tran ${ }^{3}$ and Patrick Laurenti ${ }^{1}$ \\ ${ }^{1}$ Université de Paris, Laboratoire Interdisciplinaire des Energies de Demain, Paris, France, ${ }^{2}$ UMR 6290-IGDR Expression \\ Génétique et Développement Faculté de Médecine, Rennes, France, ${ }^{3}$ Agroscope, Institute for Plant Production Systems, \\ Conthey, Switzerland
}

Keywords: plant, cell death, ion channel, shrinkage, stress

\section{INTRODUCTION}

Cell death $(\mathrm{CD})$ is a fundamental biological process that is indispensable in all living organisms (Ameisen, 2002). Phloem differentiation, root cap, aerenchyma formation, and leaf senescence are examples of developmental $\mathrm{CD}$ in plants. $\mathrm{CD}$ also occurs in response to pathogen attacks, and to abiotic stresses such as salinity, drought or pollutants. Studies of past decades characterized CD in plant, as a surprisingly complex phenomenon with various forms and multiple pathways to achieve CD. Number of molecular actors and involved-processes such as reactive oxygen species

OPEN ACCESS

Edited by:

Markus Ritter,

Paracelsus Medical University, Austria

Reviewed by:

Hubert Hannes Kerschbaum, University of Salzburg, Austria Igor Pottosin,

University of Colima, Mexico

*Correspondence:

François Bouteau

francois.bouteau@u-paris.fr

Specialty section:

This article was submitted to Cell Death and Survival,

a section of the journal

Frontiers in Cell and Developmental

Biology

Received: 28 May 2020

Accepted: 08 September 2020

Published: 19 October 2020

Citation:

Bouteau F, Reboutier D, Tran D and Laurenti P (2020) Ion Transport in

Plant Cell Shrinkage During Death. Front. Cell Dev. Biol. 8:566606. doi: 10.3389/fcell.2020.566606 (ROS), caspases, autophagic activities, mitochondrial dysfunction with release of cytochrome $\mathrm{c}$ and other apoptogenic proteins, DNA laddering, etc., have been highlighted (Reape et al., 2008; van Doorn et al., 2011). van Doorn et al. (2011) proposed a classification of plant cell deaths based on morphological characteristics. They distinguished two main classes of CD: vacuolar cell death and necrosis. During vacuolar cell death, the cell contents are removed by autophagy-like process and release of hydrolases from collapsed lytic vacuoles. Necrosis is characterized by early rupture of the plasma membrane, shrinkage of the protoplast and absence of vacuolar cell death features. They recommended abandoning terms "apoptotic-like," because the features often cited are also found in other types of CD, whereas cytological characteristics such as formation of apoptotic bodies and phagocytosis are absent in plants. One can notice however that the absence of these morphological characteristics is obviously due to the presence of a rigid cell wall in plants. On the contrary, the team of McCabe defends the idea of an apoptotic-like CD in plants. Based on features shared with animal apoptosis, this CD shows protoplast shrinkage with a central regulatory role for the mitochondria and cell degradation mediated by proteases (Reape and McCabe, 2010). This proposition has recently been reinforced with data showing that the vacuole may carry out functions that are analogous to animal phagocytosis to remove unwanted plant cells (Dickman et al., 2017). In plant CD, the presence of the cell wall prevents cell swelling. Cell shrinkage is an event recorded in most cases, being thus one of the main hallmarks of plant CD (Reape and McCabe, 2010; van Doorn et al., 2011). Accordingly, one of the most frequent technics used to quantify plant $\mathrm{CD}$ is the recording of electrolyte leakage. These leakages are supposed to be due to the rupture of the plasma membrane during necrotic cell death (van Doorn et al., 2011) or by the insertion in plasma membrane of toxins with pore forming properties (Klusener and Weiler, 1999). While in animal cells the successful execution of various forms of CD relies on early activation of distinct ion channels (Okada and Maeno, 2001; Bortner and Cidlowski, 2007), the role of ion channels during plant CD remains poorly documented although there is mounting evidence that electrolyte leakages from plant cells could be mediated by plasma membrane ion channels in responses to various $\mathrm{CD}$-inducing stresses. 


\section{ION CHANNEL REGULATIONS IN PLANT CD}

An increase in $\mathrm{K}^{+}$outward rectifying conductances (KORC) was recorded in response to various $\mathrm{CD}$-inducing microbederived molecules, such as harpins (El-Maarouf et al., 2001; Haapalainen et al., 2012), deoxinivalenol (DON) (Yekkour et al., 2015) or CD-inducing ROS stress (Demidchik et al., 2010, 2014), like ozone (Tran et al., 2013a). Conductances with different activation kinetics and selectivity (Demidchik et al., 2014) are likely triggered by GORK or SKOR channels (Tran et al., 2013a; Demidchik et al., 2014), but could also be provoked by annexins, cyclic nucleotide-gated channels and ionotropic glutamate receptors. Nonetheless, the use of $\mathrm{K}^{+}$ channel blockers decreases KORC, CD-extent (Haapalainen et al., 2012), cell shrinkage (Yekkour et al., 2015) or even activation of metacaspases (Tran et al., 2013a), proteases and endonucleases (Demidchik et al., 2014, 2018). Recently, gork11 mutants lacking $\mathrm{K}^{+}$efflux channel were also shown to have fewer autophagosomes compared to the wild-type plant upon ROS-induced CD (Demidchik, 2018). Activation of $\mathrm{K}^{+}$efflux through KORC is supposed to result in dramatic $\mathrm{K}^{+}$loss from plant cells and promotes CD (Demidchik et al., 2018) and $\mathrm{K}^{+}$loss was effectively shown to be involved in tobacco cell death induced by palmitoleic acid and ceramide (Peters and Chin, 2007). Interestingly, Nicotiana benthamiana plants undergoing oxidative stress and transiently expressing CED-9, an anti-apoptotic gene from the bcl-2 family (Craig, 1995), are capable of preventing $\mathrm{K}^{+}$efflux and maintaining intracellular $\mathrm{K}^{+}$ homeostasis (Shabala et al., 2007).

In response to ozone or DON, plant cells rapidly activate anion currents, followed by a delayed activation of KORC (Tran et al., 2013a; Yekkour et al., 2015), the whole ion efflux being thus transiently not electroneutral. Such increases in anion currents were also recorded with other CD-inducing microbederived molecules, such as harpins (Reboutier et al., 2007), fusaric acid (Bouizgarne et al., 2006), oxalic acid (Errakhi et al., 2008), cryptogein (Gauthier et al., 2007), or with ozone (Kadono et al., 2010), drought (Dauphin et al., 2001) or hydroxyl radicals (Pottosin et al., 2018). The anion currents recorded present the features of slow anion channels encoded by the slac family (Hedrich, 2012), although the instantaneous current could be carried out, to some extent, by fast activating anion channels from ALMT family (Hedrich, 2012). Either way, inhibition of anion currents with anion channel blockers reduced CDextent (Errakhi et al., 2008; Kadono et al., 2010; Yekkour et al., 2015), vacuolar collapse and cell shrinkage (Gauthier et al., 2007; Yekkour et al., 2015). It also prevented mitochondrial dysfunction (Errakhi et al., 2008; Kadono et al., 2010), caspaselike activities (Tran et al., 2013b) and the accumulation of transcripts encoding vacuolar processing enzymes (Gauthier et al., 2007; Kadono et al., 2010), that belongs to a family of proteases displaying a caspase 1-like activity.

In plant the vacuolar collapse seems a key step in cell shrinkage but to our knowledge the role of vacuolar conductances is poorly documented. Therefore, further studies are needed to decipher the role of vacuolar channels in this process.

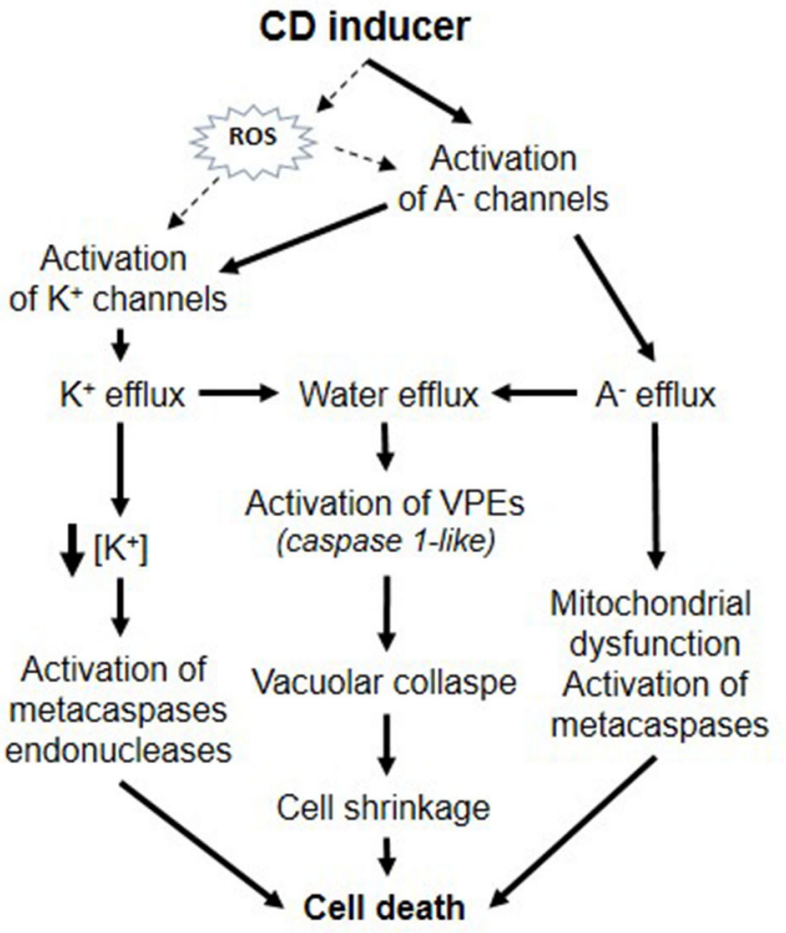

FIGURE 1 | Putative roles of ion channels during plant CD.

\section{CONCLUSION}

As a whole, these data are reminiscent of those described in numerous studies in animal cells and show that plant CD could involve specific modifications of ion transporter activities that could be significant and crucial in the successful propagation of CD (Figure 1). Activation of plasma membrane anion channels and KORC lead to solute loss leading to water release and thus, cell shrinkage could be a major hallmark in plant CD similarly to animal apoptosis. In animal cells, the induction of apoptosis volume decrease is attained by a tightly coupled operation between anion and $\mathrm{K}^{+}$channels and is prevented by application of blockers of $\mathrm{Cl}^{-}$or $\mathrm{K}^{+}$channels (Okada and Maeno, 2001). Furthermore, as in animal models, activation of ion channels was found to precede various $\mathrm{CD}$-inducing process like metacaspase activation. Some CD mechanisms in plant and animals appear mechanistically very similar. According to the sin hypothesis (Ameisen, 2002), the origin of the capacity for self-destruction may be very ancient and due to an intrinsic capacity of the cell in inducing self-destruction. The regulation of ionic channels are involved in numerous vital processes, the control of cell metabolism, volume, and permeability in all organisms and could be a conserved target due to their intrinsic potential to lead cell death. Ion channel mediated CD could thus have a deeply rooted origin and have independently evolved in eukaryotic lineages and multicellular plants and animals. 


\section{AUTHOR CONTRIBUTIONS}

FB, DR, DT, and PL conceived and wrote the manuscript. All authors contributed to the article and approved the submitted version.

\section{REFERENCES}

Ameisen, J. C. (2002). On the origin, evolution, and nature of programmed cell death: a timeline of four billion years. Cell Death Differ. 9, 367-393. doi: $10.1038 /$ sj.cdd. 4400950

Bortner, C. D., and Cidlowski, J. A. (2007). Cell shrinkage and monovalent cation fluxes: role in apoptosis. Arch. Biochem. Biophys. 462, 176-188. doi: 10.1016/j.abb.2007.01.020

Bouizgarne, B., El-Maarouf-Bouteau, H., Frankart, C., Reboutier, D., Madiona, K., Pennarun, A. M., et al. (2006). Early physiological responses of Arabidopsis thaliana cells to fusaric acid: toxic and signalling effects. New Phytol. 169, 209-218. doi: 10.1111/j.1469-8137.2005.01561.x

Craig, R. W. (1995). The bcl-2 gene family. Semin. Cancer Biol. 6, 35-43. doi: 10.1006/scbi.1995.0005

Dauphin, A., El-Maarouf, H., Vienney, N., Rona, J. P., and Bouteau, F. (2001). Effect of desiccation on potassium and anion currents from young root hairs: implication on tip growth. Physiol. Plant. 113, 79-84. doi: 10.1034/j.1399-3054.2001.1130111.x

Demidchik, V. (2018). ROS-activated ion channels in plants: biophysical characteristics, physiological functions and molecular nature. Int J Mol Sci. 19, 1263. doi: 10.3390/ijms19041263

Demidchik, V., Cuin, T. A., Svistunenko, D., Smith, S. J., Miller, A. J., Shabala, S., et al. (2010). Arabidopsis root $\mathrm{K}^{+}$-efflux conductance activated by hydroxyl radicals: single-channel properties, genetic basis and involvement in stressinduced cell death. J. Cell Sci. 123, 1468-1479. doi: 10.1242/jcs.064352

Demidchik, V., Straltsova, D., Medvedev, S. S., Pozhvanov, G. A., Sokolik, A., and Yurin, V. (2014). Stress-induced electrolyte leakage: the role of $\mathrm{K}^{+}$permeable channels and involvement in programmed cell death and metabolic adjustment. J. Exp. Bot. 65, 1259-1270. doi: 10.1093/jxb/eru004

Demidchik, V., Tyutereva, E. V., and Voitsekhovskaja, O. V. (2018). The role of ion disequilibrium in induction of root cell death and autophagy by environmental stresses. Funct Plant Biol. 45, 28-46. doi: 10.1071/FP16380

Dickman, M., Williams, B., Li, Y., de Figueiredo, P., and Wolpert, T. (2017). Reassessing apoptosis in plants. Nat. Plants 3, 773-779. doi: 10.1038/s41477-017-0020-x

El-Maarouf, H., Barny, M. A., Rona, J. P., and Bouteau, F. (2001). Harpin, a hypersensitive response elicitor from Erwinia amylovora, regulates ion channel activities in Arabidopsis thaliana suspension cells. Febs Lett. 497, 82-84. doi: 10.1016/S0014-5793(01)02441-3

Errakhi, R., Meimoun, P., Lehner, A., Briand, J., Corbineau, F., Rona, J. P., et al. (2008). Anion channel activity is necessary to induce ethylene synthesis and programmed cell death in response to oxalic acid. J. Exp. Bot. 59, 3121-3129. doi: $10.1093 /$ jxb/ern 166

Gauthier, A., Lamotte, O., Reboutier, D., Bouteau, F., Pugin, A., and Wendehenne, D. (2007). Cryptogein-induced anion effluxes: electrophysiological properties and analysis of the mechanisms through which they contribute to the elicitortriggered cell death. Plant Signal. Behav. 2, 89-98. doi: 10.4161/psb.2.2.4015

Haapalainen, M., Dauphin, A., Li, CM., Bailly, G., Tran, D., Briand, J., et al. (2012). HrpZ harpins from different Pseudomonas syringae pathovars differ in molecular interactions and in induction of anion channel responses in Arabidopsis thaliana suspension cells. Plant Physiol Biochem. 51, 168-174. doi: 10.1016/j.plaphy.2011.10.022

Hedrich, R. (2012). Ion channels in plants. Physiol. Rev. 92, 1777-1811. doi: 10.1152/physrev.00038.2011

Kadono, T., Tran, D., Errakhi, R., Hiramatsu, T., Meimoun, P., Briand, J., et al. (2010). Increased anion channel activity is an unavoidable

\section{ACKNOWLEDGMENTS}

This study contributes to IdEx University of Paris ANR-18IDEX-0001.

event in ozone-induced programmed cell death. Plos ONE 5:e13373. doi: 10.1371/journal.pone.0013373

Klusener, B., and Weiler, E. W. (1999). Pore-forming properties of elicitors of plant defense reactions and cellulolytic enzymes. FEBS Lett. 459, 263-266. doi: 10.1016/S0014-5793(99)01261-2

Okada, Y., and Maeno, E. (2001). Apoptosis, cell volume regulation and volumeregulatory chloride channels. Comp. Biochem. Physiol. A Mol. Integr. Physiol. 130, 377-383. doi: 10.1016/S1095-6433(01)00424-X

Peters, J., and Chin, C. K. (2007). Potassium loss is involved in tobacco cell death induced by palmitoleic acid and ceramide. Arch. Biochem. Biophys. 465, 180-186. doi: 10.1016/j.abb.2007.05.025

Pottosin, I., Zepeda-Jazi, I., Bose, J., and Shabala, S. (2018). An anion conductance, the essential component of the hydroxyl-radical-induced ion current in plant roots. Int. J. Mol. Sci. 19:897. doi: 10.3390/ijms19030897

Reape, T. J., and McCabe, P. F. (2010). Apoptotic-like regulation of programmed cell death in plants. Apoptosis 15, 249-256. doi: 10.1007/s10495-0090447-2

Reape, T. J., Molony, E. M., and McCabe, P. F. (2008). Programmed cell death in plants: distinguishing between different modes. J. Exp. Bot. 59, 435-444. doi: $10.1093 / \mathrm{jxb} / \mathrm{erm} 258$

Reboutier, D., Frankart, C., Briand, J., Biligui, B., Rona, J. P., Haapalainen, M., et al. (2007). Antagonistic action of harpin proteins: HrpWea from Erwinia amylovora suppresses HrpNea-induced cell death in Arabidopsis thaliana. J. Cell. Sci. 120, 3271-3278. doi: 10.1242/jcs.011098

Shabala, S., Cuin, T. A., Prismall, L., and Nemchinov, L. G. (2007). Expression of animal CED-9 anti-apoptotic gene in tobacco modifies plasma membrane ion fluxes in response to salinity and oxidative stress. Planta 227, 189-197. doi: 10.1007/s00425-007-0606-z

Tran, D., El-Maarouf-Bouteau, H., Rossi, M., Biligui, B., Briand, J., Kawano, T., et al. (2013a). Post-transcriptional regulation of GORK channels by superoxide anion contributes towards increases in outward rectifying $\mathrm{K}^{+}$currents. New Phytol. 198, 1039-1048. doi: 10.1111/nph.12226

Tran, D., Rossi, M., Biligui, B., Kawano, T., Mancuso, S., and Bouteau, F. (2013b). Ozone-induced caspase-like activities are dependent on early ion channel regulations and ROS generation in Arabidopsis thaliana cells. Plant Signal. Behav. 8:e25170. doi: 10.4161/psb.25170

van Doorn, W. G., Beers, E. P., Dangl, J. L., Franklin-Tong, V. E., Gallois, P., HaraNishimura, I., et al. (2011). Morphological classification of plant cell deaths. Cell Death Differ. 18, 1241-1246. doi: 10.1038/cdd.2011.36

Yekkour, A., Tran, D., Arbelet-Bonnin, D., Briand, J., Mathieu, F., Lebrihi, A., et al. (2015). Effect of Fusarium mycotoxin deoxynivalenol on Nicotiana tabacum cells: early events lead to programmed cell death. Plant Sci. 238, 148-157. doi: 10.1016/j.plantsci.2015. 06.004

Conflict of Interest: The authors declare that the research was conducted in the absence of any commercial or financial relationships that could be construed as a potential conflict of interest.

Copyright (C) 2020 Bouteau, Reboutier, Tran and Laurenti. This is an open-access article distributed under the terms of the Creative Commons Attribution License (CC $B Y)$. The use, distribution or reproduction in other forums is permitted, provided the original author(s) and the copyright owner(s) are credited and that the original publication in this journal is cited, in accordance with accepted academic practice. No use, distribution or reproduction is permitted which does not comply with these terms. 